〔2〕チグラー型触媒によるブタジェンと

$$
\text { イソプレンの共重合*** }
$$

(1963 年 4 月 11 日受理)

住 江太郎*・佐々木毅一**

山崎 升** 神 原 周**

\begin{abstract}
要 旨 $\mathrm{Al}\left(\mathrm{C}_{:} \mathrm{H}_{5}\right)_{3}-\mathrm{TiCl}_{4}$ 系触媒を用いてブタジエンとイソプレンの共重合を行ない，次のことを見出 した。 $\mathrm{Al} / \mathrm{Ti}$ モル比=1.25, 1.50 いずれの場合にもモノマー反応性比 $r_{B}, r_{I}$ はほぼ 1 に等しいが, 共重合の 速さは前者の方が大きい。いずれの場合もホモポリマーは生成しない。コポリマーはベンゼン不溶分と可溶分 に分けられるがそれらの組成, ミクロ粠造は等しい。可溶分は分別沈殿によっていくつかの部分に分けられ，そ れらの組成および $[\eta]$ は異なるがミクロ構造は等しい。コポリマー中のブタジエンおよびイソプレンのミク

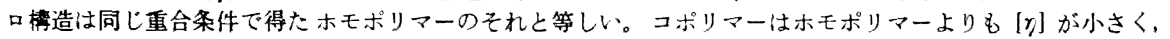

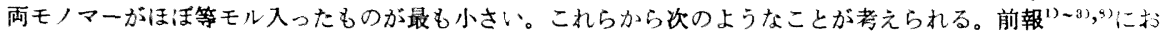
いてこの采の触媒には数種類の活性点が存在すると推定したが，本報の実験結果からもそれが支持される。共 重合反応においてブタジエンおよびイソプレンは各々の重合の立体规則性を互いに乱さない。ポリマーの生長 末端つモ/マー単位に，それと同種のモ/マーが近づたときよりも異種のモ/マーが近づいたよきに連鎖移 動が起こりやすい。
\end{abstract}

\section{1. 緒言}

前報1) 31,8\}にひきつゔきチグラー型触媒によるオレフ ィン類の共重合の一つとして, 化学的構造, 性質などの よく似たプタジェンとインプレンの $\mathrm{Al}\left(\mathrm{C}_{2} \mathrm{H}_{5}\right)_{3}-\mathrm{TiCl}_{4}$ 采 触媒による共重合を行ない, 重合条件のコポリマー組 成, 共重合の速さなよに的ぼす影響を調べ，これらの実 験結果をもとにしてチグラー型触媒の本性について考察 した。

\section{2. 実験}

\section{1 試 料}

触媒成分の $\mathrm{Al}\left(\mathrm{C}_{2} \mathrm{H}_{5}\right)_{3}, \mathrm{TiCl}_{4}$, 溶媒の $n$-へキサン, ノマーのブタジェン, イソプレンなどは前報1),2) 記載の ものを使用した。

\section{2 重合反応器およひ重合反応}

重合反応器は前報”と同じ五つ口セパラブルフラスコ を用い, 水冷浴中で反応を行なった(反応采の温度は 1 $3^{\circ} \mathrm{C}$ )。インプレンは注射器を用いて反応器上部のゴム板 を通して器内に仕込み, ブタジェンはコールドトラップ に捕集したものを気化させてモノマー仕込口から器内の nーヘキサン中に吹込み吸収させた。触媒成分の添加方 法, 重合生成物の後処理などは前報”と同じである。

\section{3 ポリマーの収量測定}

生成ポリマーを細かく切ってこれに多量のベンゼンを 加え, 1 夜放置したのち遠心分離機により不溶分を分離

\footnotetext{
* 協和酸醉工業株式会社(東京都千代田区大手町 1 の 4) 現在の勤務先 日本合成ゴ株式会社四日市工埸研究所 (三重県四日市市川尻町 100)

** 東京工業大学资源化学研究所(東京都目黒区大阔山 1)

****オレフィン類の共重合第 4 報とする。
}

した。不溶分, 可溶分を凍結乾燥して重量をはかり, 全 収量, ベンゼン不溶分, 可溶分％を求めた。

2.4 コポリマー組成およびミクロ構造の求め方

3.2 に述べるように生成物中にはホモポリマーは存在 しないので, 生成ポリマーはすべてコポリマーと考えら れ，また， 3.3 に述べるようにベンゼン不溶分も可溶分 も組成扰よびクロ構造が等しいから，可溶分についた 組成およびミク口構造を求め重合条件のそれらに及ぼす 影響を調べた。可溶分のベンゼン溶液を岩塩板上に塗 り, 隇圧乾燥して岩塩板上にコポリマーの薄膜をつくり, これを赤外分析用試料とした。また全ポリマーについて はこれにベンゼンを加え, 1 夜放置したのち, 溶けずに 膨潤している不溶分をよくすりつぶし，可溶分と同様の 方法で赤外分析用試料をつくった。赤外吸収スペクトル の測定には臭津自記赤外分光光度計 IR-27 型を用いた。 Table 1 に示すようにイソプレンについては著者ら”の 測定した各結合様式の吸光倸数, ブタジェンについては D. Morero ${ }^{5)}$ の測定した 各結合様式の吸光倸数を用い た。これらはポリマーの二硫化炭素溶液についての吸光 係数であるが，これらの值をそのまま薄膜法に適用して 両ホモポリマーの各結合様式の相対的濃度を求めても, 溶液法により求めた分析值と $1 \sim 2 \%$ の誤差䇛囲で一致 することおよび Table 3 欄外に示すように薄膜法と溶 液法による分析值はよく一致するから，コポリマーの分 析にもこれらの吸光係数をそのまま用いて, ブタジェン およびイソプレンのそれぞれの各結合様式の相対的浱度 を求め, 次にこれらの值から両モノマー単位の含有率を 計算した。この分析法の信頼性を確かめるた加に既知割 合の両ホモポリマーの混合物をつくり分析した結果, 混 合物組成の測定做と理論值は $2 \%$ 以内の誤差で一致し， 
Table 1. Extinction coefficients* used in analysis of copolymers.

polyisoprene

\begin{tabular}{c|c|c}
\hline \hline \multirow{2}{*}{$\begin{array}{c}\text { Number of } \\
\text { frequency } \\
\left(\mathrm{cm}^{-1}\right)\end{array}$} & \multicolumn{2}{|c}{ Microstructure } \\
\cline { 2 - 3 } & cis-1,4 & 3,4 \\
\hline 836 & 19.9 & 1.95 \\
890 & 1.79 & 145 \\
\hline
\end{tabular}

\begin{tabular}{c|c|c|c}
\multicolumn{2}{c}{ polybutadiens $^{s)}$} \\
\hline \hline $\begin{array}{c}\text { Number of } \\
\text { frequency } \\
\left(\mathrm{cm}^{-1}\right)\end{array}$ & \multicolumn{3}{|c}{ Microstructure } \\
\cline { 2 - 4 } & cis-1,4 & trans-1,4 & 1,2 \\
\hline $732 \sim 741$ & 31.0 & 0 & 1.68 \\
910 & 0.58 & 0 & 145 \\
966 & 3.30 & 126 & 4.48 \\
\hline
\end{tabular}

* Extinction coefficients were measured with $\mathrm{CS}_{2}$ solution and expressed in $l \cdot \mathrm{mol} \cdot \mathrm{cm}^{-1}$.

また，同様の分析法を繰り返した場合の混合物組成およ び両ホモポリマーの結合様式の相対的濃度の分析誤差は 1\%以内であった。

\section{5 分別沈殿}

ポリブタジェンとポリイソプレンは性質がきわめて似
ているので, 前報 ${ }^{1)}{ }^{21}{ }^{2}$,4) 記載の溶剂-沈殿剂系を用いた分 別沈殿では両者を分別することができなかった。各種の 溶剤, 沈殿剂を組合せた采で分別沈殿を試みた結果, ヘ ンゼン・n-ブタノール混合液を溶剂に, メタノール(以 下 $\mathrm{MeOH}$ と略す)を沈殿剤に用いた系で両者が比較的 よく分別できることを見出し，この系を用いて共重合生 成物の分別沈殿を行なって，ホモポリマーの有無を調へ た。まず(ポリマー $1 \mathrm{~g}) /(75 \mathrm{ml}$ ベシゼン $+25 \mathrm{ml} n$-プ

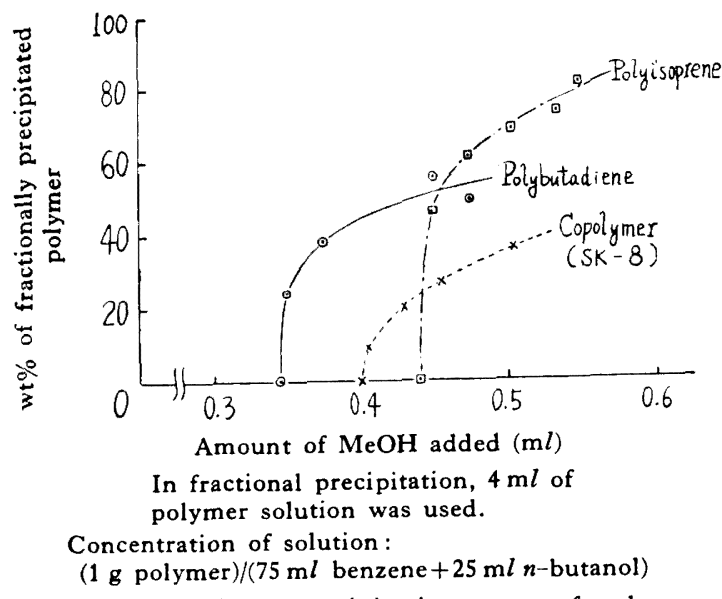

Fig. 1. Fractional precipitation curve of polymers.

Table 2. Experimental $\left(\mathrm{Al} / \mathrm{Ti}\right.$ mol ratio $=1.25$, Polymerization temperature $1 \sim 3^{\circ} \mathrm{C}$, Solvent : $n$-Hexane $\left.100 \mathrm{ml}\right)$

\begin{tabular}{|c|c|c|c|c|c|c|c|c|}
\hline \multirow{2}{*}{$\begin{array}{l}\text { Expt. } \\
\text { No. }\end{array}$} & \multicolumn{2}{|c|}{$\begin{array}{l}\text { Amount of monomer } \\
\text { charged } \\
(\mathrm{mol})\end{array}$} & \multicolumn{2}{|c|}{$\begin{array}{l}\text { Content of isoprene } \\
(\mathrm{mol} \%)\end{array}$} & \multirow{2}{*}{$\begin{array}{l}\text { Polymeri- } \\
\text { zation } \\
\text { time } \\
\text { (nin) }\end{array}$} & \multirow{2}{*}{$\begin{array}{c}\text { Yield of } \\
\text { polymer } \\
(\%)\end{array}$} & \multicolumn{2}{|c|}{$\begin{array}{l}\text { Composition of } \\
\text { polymer } \\
(\%)\end{array}$} \\
\hline & Butadiene & Isoprene & $\begin{array}{l}\text { in } \\
\text { Monomer }\end{array}$ & in & & & $\begin{array}{c}\text { Benzene } \\
\text { soluble part }\end{array}$ & $\begin{array}{l}\text { Benzene in- } \\
\text { soluble part }\end{array}$ \\
\hline SK-2 & 0.076 & 0.074 & 49 & 57 & 30 & 3.2 & 88 & 12 \\
\hline SK-3 & 0.127 & 0.023 & 14 & 19 & 21 & 6.3 & 91 & 9 \\
\hline SK-5 & 0.107 & 0.043 & 29 & 29 & 23 & 7.1 & 80 & 20 \\
\hline SK-6 & 0.045 & 0.105 & 70 & 69 & 42 & 4.6 & 78 & 22 \\
\hline SK-8 & 0.075 & 0.075 & 50 & 52 & 30 & 5.6 & 82 & 18 \\
\hline SK-9 & 0.075 & 0.075 & 50 & 47 & 47 & 2.9 & 94 & 6 \\
\hline SK-14 & 0.113 & 0.037 & 25 & 31 & 90 & 11.6 & 82 & 18 \\
\hline S-140 & 0 & 0.300 & 100 & - & 300 & 38 & 75 & 25 \\
\hline S-141 & 0.075 & 0.225 & 75 & 77 & 300 & 42 & 73 & 27 \\
\hline S-142 & 0.150 & 0.150 & 50 & 54 & 300 & 41 & 84 & 16 \\
\hline S-143 & 0.225 & 0.075 & 25 & 28 & 300 & 34 & 73 & 27 \\
\hline S-145 & 0.300 & 0 & 0 & - & 300 & 42 & 76 & 24 \\
\hline $\mathrm{S}-210$ & 0.150 & 0 & 0 & - & 60 & 24 & 34 & 66 \\
\hline S-214 & 0.150 & 0 & 0 & - & 30 & 11 & 67 & 33 \\
\hline
\end{tabular}

a) $30^{\circ} \mathrm{C}$ Toluene solution, b) $25^{\circ} \mathrm{C}$ Toluene solution 
タノール)の溶液をつくり,その $4 \mathrm{~m} l$ をピペットで小型 三角フラスコに採取し，マグネチックスターラーでかき まぜながら沈殿剤の $\mathrm{MeOH}$ を滴下した。分別沈殿量の 測定は前報1 と同様の方法で行なった。Fig. 1 に示すよ うにポリブタジェンは約 $0.35 \mathrm{ml} の \mathrm{MeOH}$, ポリイソ プレンは約 $0.44 \mathrm{~m} l$ の $\mathrm{MeOH}$ を添加したときにいず れも急激に沈殿し始めるので両者は明らかに区別するこ とができる。コポリマーは組成，[凤]などによっていく ぶん沈殿点が異なるがこの中間で沈殿を開始する。

\section{6 コポリマーの加硫}

試料が少ないのでこれに等量の天然ゴムを混せ，全ポ リマー $100 \mathrm{~g}$ に対し HAF ブラック $50 \mathrm{~g}$ ，ステアリン 酸 $0.1 \mathrm{~g}$, 亜鉛華 $5.0 \mathrm{~g}$, ノクセラー CZ $1.0 \mathrm{~g}$, イナ ウ $2.3 \mathrm{~g}$ の処方で $138^{\circ} \mathrm{C}$ において $45 \mathrm{~min}$ プレス加硫 した。

\section{3. 実験結果と考察}

\section{1 実験結果一覧表}

実験結果を Table 2 にまとめて示す。

\section{2 ホモポリマーの有無}

共重合生成物中にホモポリマーが存在するか否かを調 ベるために, 共重合生成物のベンゼン可溶分について 2.5 に述べた方法により分別沈殿を行なった。Fig. 1 に示すように共重合生成物の分别沈殿においてはポリブ
タジェンの沈殿点で沈殿を生ぜず，また，その分別沈殿 曲線はポリイソプレンの沈殿点付近で届曲点をもたない ことから，このなかにホモポリマーは存在しないと考え られる。ポリイソプレンにはベンゼン不溶分はほとんど ないが，ポリブタジェンには相当量の不溶分が存在する から，もしホモポリマーが存在するならば共重合生成物 のベンゼン不溶分と可溶分の組成は 異なるはずである。 実際には次節に述べるように不溶分と可溶分の組成は等 しいので，不溶分中にもホモポリマーは存在しないと考 えられる。

\section{3 ベンゼン不溶分, 可溶分の組成とミク口構造}

共重合生成物はベンゼン不溶分と可溶分からできてい るが,これらの組成㧍よび構造を次のようにして調べた。 不溶分, 可溶分に分ける前の全ポリマーと可溶分の赤外 吸收スペクトルを測定し、これから 2.4 に述べた方法に よりそれらの組成およびミクロ構造を調べた。Table 3 に示すように両者の組成およびミク口構造は等しい。ま た同表に示すようにポリブタジェンについても全ポリマ 一とベンゼン可溶分のミクロ構造は等しい.このことか らコポリマーおよびポリブタジェンの不溶分も可溶分も 本質的には等しく，両者を生成する活性中心の種類に区 別はないと考えられ, 不溶分は重合の生長反忘の途中あ るいは終了したのちに二次的な橋かけ反応によって網状 化が起こり不溶化したものと推定される。これは,この

results.

\begin{tabular}{|c|c|c|c|c|c|c|}
\hline \multirow{3}{*}{$\begin{array}{c}{\left[\gamma_{i}\right] \text { of }} \\
\text { benzene } \\
\text { soluble } \\
\text { part }\end{array}$} & \multicolumn{5}{|c|}{ Microstructure $(\%)$} & \multirow{3}{*}{ Remarks } \\
\hline & \multicolumn{2}{|c|}{ Isoprene } & \multicolumn{3}{|c|}{ Butadiene } & \\
\hline & cis $-1,4$ & 3,4 & cis- $-1,4$ & trans- 1,4 & 1,2 & \\
\hline- & 98 & 2 & 70 & 28 & 2 & \multirow{7}{*}{$\mathrm{Al} / \mathrm{Ti}=1.50$} \\
\hline $1.27^{\mathrm{a})}$ & 98 & 2 & 75 & 23 & 2 & \\
\hline $0.95^{\mathrm{a})}$ & 98 & 2 & 73 & 26 & 1 & \\
\hline $0.77^{\mathrm{a})}$ & 98 & 2 & 75 & 24 & 1 & \\
\hline $0.80^{\mathrm{a}}$ & 98 & 2 & 72 & 26 & 2 & \\
\hline- & 97 & 3 & 73 & 24 & 3 & \\
\hline $0.69^{\mathrm{a})}$ & 99 & 1 & 76 & 21 & 3 & \\
\hline $1.82^{b)}$ & 98 & 2 & - & - & - & \multirow[t]{4}{*}{ Homopolymerization of isoprene } \\
\hline $1.13^{\mathrm{b})}$ & 98 & 2 & 77 & 21 & 2 & \\
\hline $0.76^{\mathrm{b})}$ & 99 & 1 & 73 & 25 & 2 & \\
\hline $0.93^{b)}$ & 99 & 1 & 71 & 26 & 3 & \\
\hline $1.27^{\mathrm{b})}$ & - & - & 76 & 21 & 3 & \multirow{3}{*}{ Homopolymerization of butadiene } \\
\hline $2.15^{a)}$ & - & - & 77 & 22 & 1 & \\
\hline $1.80^{\mathrm{a})}$ & - & … & 69 & 30 & 1 & \\
\hline
\end{tabular}


Table 3. Composition and microstructure of copolymer and polybutadiene.

(Al/Ti mol ratio 1.25 , Polymerization temperature $1 \sim 3^{\circ} \mathrm{C}$, Polymerization time $30 \mathrm{~min}$ )

\begin{tabular}{|c|c|c|c|c|c|c|c|c|c|c|}
\hline & \multirow{3}{*}{$\begin{array}{l}\text { Yield } \\
\left(w t^{\circ}\right)\end{array}$} & \multirow{3}{*}{$\begin{array}{c}\text { Benzene } \\
\text { soluble } \\
\text { part } \\
(w t \%)\end{array}$} & \multirow{3}{*}{$\begin{array}{l}\text { Isoprene } \\
\text { content } \\
\text { in } \\
\text { monomer } \\
(\text { mol } \%)\end{array}$} & & \multirow{3}{*}{$\mid \begin{array}{c}\text { Isoprene } \\
\text { content } \\
\text { in } \\
\text { copolymer } \\
(\mathrm{mol} \%)\end{array}$} & \multicolumn{5}{|c|}{ Microstructure (\%) } \\
\hline & & & & & & \multicolumn{2}{|c|}{ Isoprene } & \multicolumn{3}{|c|}{ Microstructure (\%) } \\
\hline & & & & & & cis $-1,4$ & 3,4 & cis- 1,4 & $\begin{array}{c}\text { trans- } \\
1,4\end{array}$ & 1,2 \\
\hline & 41 & 84 & 50 & $\begin{array}{l}\text { Total } \\
\text { polymer }\end{array}$ & & & 1 & 73 & 25 & 2 \\
\hline$(\mathrm{S}-142)$ & & & & $\begin{array}{l}\text { Benzene* } \\
\text { soluble part }\end{array}$ & 55 & 98 & 2 & 72 & 25 & 3 \\
\hline $\begin{array}{l}\text { Polybuta- } \\
\text { diene }\end{array}$ & 42 & 76 & - & $\begin{array}{l}\text { Total } \\
\text { polymer }\end{array}$ & - & - & - & 76 & 21 & 3 \\
\hline & & & 1 & $\begin{array}{l}\text { Benzene } \\
\text { soluble part }\end{array}$ & - & - & - & 76 & 21 & 3 \\
\hline
\end{tabular}

* Composition and microstructure of the copolymer measured with $\mathrm{CS}_{2}$ soln.

Isoprene content $54 \%$, Isoprene: cis $-1,498 \%, 3,42 \%$, Butadiene: cis-1, $474 \%$, trans-1, $425 \%, 1,21 \%$, Total found $\% 96 \%$

采の触媒に 1 種類のみの活性中心が存在することを意味 するものではなく，3.8に述べるように，この系の触媒 には数種類の活性中心が存在するが, その中で不溶分, 可溶分を生成寸る活性中心の区別はないということであ る。 $\mathrm{Al}\left(\mathrm{C}_{2} \mathrm{H}_{5}\right)_{3}-\mathrm{TiCl}_{4}$ 系触媒を用いて得たポリイソプレ ンには不溶分はほとんどないが，ポリブタジェンには常 にこれが生成することから，コポリマーの不溶分はコポ リマー中のブタジェン単位から橋かけ反応が起こり, 不 溶化したものと考えられる。

\section{4 コポリマー中のイソプレンおよびブタジェンの 結合梯式}

Table 2 に示すように, コポリマー中のブタジェンお よぴイソプレンの結合様式は触媒成分比 ( $\mathrm{Al} / \mathrm{Ti}$ モル比), 収率, 重合時間, コポリマー組成などには無関係にほぼ 一定で各ホモポリマーのそれと等しい。既報のプロピレ ンープタジェン2), エチレンーイソプレンタ)共重合におい てコポリマー中のブタジェンおよびィソプレンの結合様 式はホモポリマーの場合と異なるが,ブタジェンーイソプ レンコポリマーにおいてはブタジェンもインプレンもと もにその結合様式はホモポリマーの場合と同じである。 このことからポリマー鎖の生長末端に付加寸る両モノマ 一の結合様式は, 末端のモノマー単位の種類や立体構造 に影響されないと考えられる。これは両モノマーの化学 的構造, 性質などがよく似ているため, 共重合の場合に も互いにコモノマーの重合の立体規則性を乱さないので あろらと推定される。

\section{5 モノマー反応性比 (mrr)}

$\mathrm{Al} / \mathrm{Ti}=1.25$ の場合には Fig. 2 に示すようなモ/ 一・コポリマー組成曲線を得た。实験做はほぼ対角線上 に职り,これから $\mathrm{mrr}$ と $r_{B} \fallingdotseq r_{I} \fallingdotseq 1$ いう值が得られ

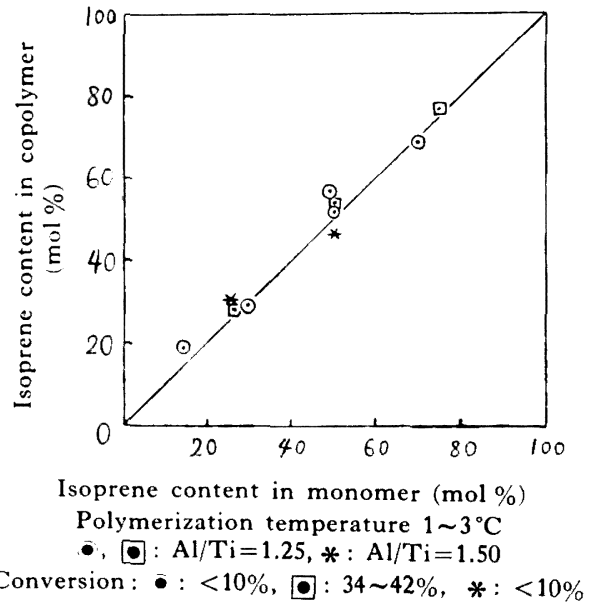

Fig. 2. Copolymer composition curve.

た。これらは重合率を $10 \%$ 以内に収めた場合であるが, 図中り印で示すように重合率を $40 \%$ 程度に上げても 仕込みモノマー組成とほぼ同じ組成のコポリマーを生成 することからも $r_{B} \fallingdotseq r_{I} \fallingdotseq 1$ の関係が支持される。また, $\mathrm{Al} / \mathrm{Ti}=1.50$ の場合には同図中 *印で示す 2 点につい て夷験を行なった。実験例が少ないので断定することは できないが, この場合にもほぼ対角線上にのると考えら れる。これらのことから $\mathrm{Al} / \mathrm{Ti}$ モル比が変わっても mrr には変化がなくほぼ $r_{B} \fallingdotseq r_{I} \fallingdotseq 1$ で, 触媒成分比に は無関係に常に仕込みモ, マ一組成と同じ組成のコポリ マーが生成すると推定される。

般に, 両モノマーの触媒表面への吸着のしやすさが 買なる場合には仕込みモ, マー牀度と触媒表面に吸着し 
ている実効モノマー濃度との間には比例関倸が成り立た ず，仕込みモノマー組成と実効モノマー組成は全く異な るので, 仕込みモノマー濃度をもとにして mrr 求为 ても理論的にはあまり意味がない。しかしながらブタジ エンとインプレンの共重合においては, どちらのモノマ 一に対しても触媒の吸着能は同程度の大きさをもつと考 えられるので, 仕込みモ, マー㗳度と触媒表面上に吸着 している実効モノマー漕度との間には比例関保が成立 し，仕込みモノマー組成と寒効モノマー組成上はほぼ、等 しいと考えられる。それゆえこの場合には仕込みモノ、 一濃度を基にして mrr を求妨ること分意義あるこ とで,この $\mathrm{mrr}$ をもとにしてコポリマー組成, 共重合 の速さなどを諭ずることができる。

\section{6 コポリマー組成と極限粘度}

コポリマーのベンゼン可溶分の $[r]$ とコポリマー組成 との関倸は Fig. 3 に示すごとく、コポリマーの $[r] は$

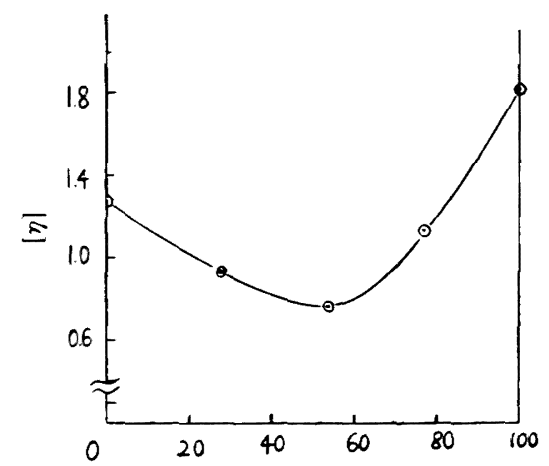

Content of isoprene in copolymer ( $\mathrm{mol} \%$ )

Viscosity was measured at $25^{\circ} \mathrm{C}$ in toluene solution.

$\mathrm{Al} / \mathrm{Ti}=1.25$, Polymerization temp. $1 \sim 3^{\circ} \mathrm{C}$,

Polymerization time $5 \mathrm{hr}$

Fig. 3. Relation between copolymer composition and intrinsic vicosity.

ホモポリマーのそれよりも小さく，両モノマーがほぼ等 モルの組成のコボリマーの[列が最も小さい。これは既 報のプロピレン・イソプレン1), エチレン・イソプレンタ 共重合においてコポリマーはポリイソプレンよりも $\left[r_{0}\right]$ が小さく，また既報のプロピレン・ブタジェンコポリマ

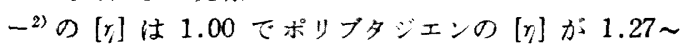
2.15 (Table 2 参照) に比べて小さいという実験結果と 一致する。これはポリマーの生長末端のモノマー岸位と 異なる種類のモノマーが末端に近づいた場合, 同種のモ ノマーの場合よりも連鎖移動が起こりやすくなるためと

考えられるが，その原因は不明である。

3.7 触媒成分比 (A1/Ti モル比) と共重合の速さおよ びコポリマーの組成

$\mathrm{Al} / \mathrm{Ti}=1.25$ の場合にはブタジェンもインプレンも単
独重合の速さほほぼ同じぐらい (Table 2, S-140, 145) であり,この触媒で共重合を行なえば 3.5 に过べたよう に $r_{B} \fallingdotseq r_{I} \fallingdotseq 1$ で, 仕込みモノマー組成とほぼ同じ組成 のコポリマーが生成する。 $\mathrm{Al} / \mathrm{Ti}$ モル比を 1.25 から 1.50 に変えると単独重合の速さはイソプレンでは低下 し6), ブタジェンではやや増加する7)ので, $\mathrm{Al} / \mathrm{Ti}=1.50$ で共重合を行なえば $\mathrm{Al} / \mathrm{Ti}=1.25$ の場合に比べてコポ リマー組成や共重合の速さが変化するであろうと考えて 実験を行なったところ (SK-9)， $\mathrm{Al} / \mathrm{Ti}=1.25$ の場合に 比ベて共重合の速さは著しく低下したが, 仕込みモノマ 一組成とコポリマー組成の関係は $\mathrm{A} 1 / \mathrm{Ti}=1.25$ の場合

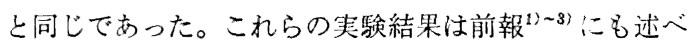
たように触媒表面へのモ, マーの吸着ということを考え ると比較的良く説明できる。ブタジェンとインプレンは その化学的構造, 性質などがよく似ているため触媒表面 への吸着のしやすさは同じぐらいで, 触媒表面には仕込 みモノマー比と同じ割合で両モノマーが吸着しており， また，前報1ー3)に述べたように活性中心のまわりの触媒 表面上に吸着したモノマーが重合に関与すると考えると 仕込みモノマー組成が同じならば, 共重合の各素反応の 速度定数 $k$ の大小関係からコポリマーの組成や, 共重合 の速さを論ずることができる。 $\mathrm{Al} / \mathrm{Ti}$ モル比にかかわら ず $r_{B} \fallingdotseq r_{I} \fallingdotseq 1$ であることから常に $k_{B B} \fallingdotseq k_{B I}, k_{I I} \fallingdotseq k_{I B}$ の関係が導かれるが，これはプタジェンとイソプレンは その化学構造, 性質などがよく似ているため, ポリマー の生長末端のモノマー単位の種類によって, 次に付加す るモノマーの種類が規制されないためであろらと考えら れる。さきに述べたように $\mathrm{Al} / \mathrm{Ti}=1.25$ ではブタジェ ンとインプレンの単独重合の速さはほぼ等しく, $\mathrm{Al} / \mathrm{Ti}$ $=1.50$ ではブタジェンの方が速い。それゆえ $\mathrm{Al} / \mathrm{Ti}=$ 1.25 では $k_{B B} \fallingdotseq k_{I I}$ で,したがって $k_{B B} \fallingdotseq k_{B I} \fallingdotseq k_{I B} \fallingdotseq k_{I I}$ となり, $\mathrm{Al} / \mathrm{Ti}=1.50$ では $k_{B B}^{\prime} \gg k_{I I}^{\prime}$ で, したがって

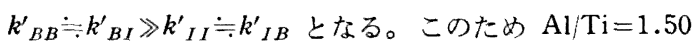
ではポリマーの生長末端のモノマー単位がブタジェンの 場合, その次に付加するモ, マーの種類によらず $\mathrm{Al} / \mathrm{Ti}$ $=1.25$ の場合に比べて付加の速さはやや大きいが,生長 末端ボイソプレンの場台にはその次に付加するモノマー の種類によらず, $\mathrm{Al} / \mathrm{Ti}=1.25$ の場合に比べて付加の速 さはきわめて小さく, $k^{\prime}{ }_{B B} \doteqdot k^{\prime}{ }_{B I}>k_{I I} \fallingdotseq k_{I B} \fallingdotseq k_{B B} \fallingdotseq k_{B I}$ $\gg k^{\prime}{ }_{I I} \fallingdotseq k^{\prime}{ }_{I B}$ となるので, 共重合の速さも低下すると考 えられる。

\section{8 多種の活性中心の存在}

前報3) でチグラー型触媒には数種類の活性中心が存在 すると推論したが，次に述べる実験結果からもこれが支 持される。すなわち Table 4 に示すようにコポリマー を分別沈殿して得られる Fraction I と II では $[r]$ お よびョポリマーの組成が異なっている。1 種類の活性中 心から生したものならば $[\eta]$ のみによって分別され，ど 
Table 4. Composition and microstructure of fractionated copolymer (SK-8).

\begin{tabular}{|c|c|c|c|c|c|c|c|}
\hline & \multirow{3}{*}{$\begin{array}{l}\text { Isoprene } \\
\text { content } \\
\text { (mol\%) }\end{array}$} & \multicolumn{5}{|c|}{ Microstructure (\%) } & \multirow{3}{*}[\eta]{$^{* * *}$} \\
\hline & & \multicolumn{2}{|c|}{ Isoprene } & \multicolumn{3}{|c|}{ Butadiene } & \\
\hline & & cis $-1,4$ & 3,4 & cis- 1,4 & trans $-1,4$ & 1,2 & \\
\hline Fraction $\mathrm{I}^{*}$ & 49 & 98 & 2 & $71 \sim 72$ & 27 & $1 \sim 2$ & 1.75 \\
\hline Fraction II** & 53 & 98 & 2 & $71 \sim 73$ & $26 \sim 28$ & 2 & 0.45 \\
\hline $\begin{array}{l}\text { Total polymer before } \\
\text { fractionation }\end{array}$ & 52 & 98 & 2 & 72 & 26 & 2 & 0.80 \\
\hline
\end{tabular}

* Fractionally precipitated polymer $0 \sim 41 \mathrm{wt} \%$,

*** Measured at $30^{\circ} \mathrm{C}$ in toluene solution

の部分をとってもコポリマーの組成は等しいはす゚である が,このように組成が異なるのは異種の活性中心から生 成した組成の異なるコポリマーが存在し，かりに同じ重 合度のコポリマーをとってもその組成の差によって沈殿 点を異にするため, このように Fraction によって組成 分析值が異なるのであろう。

この組成分析には 2.4 に述べた赤外吸収スペクトル による方法を用いたが，同一原料から二つの分析用試料 をつくりそれらを分柠した場合の誤差は，1\% 以内であ ることから Fraction I, II の組成の差は分析誤差によ るものでないことは明らかである。また, Table 5 に示 すようにポリブタジェンのェチルェーテル抽出残渣は量 的にはきわめてわずかであるが，その結合様式は抽出前 のものに比べるときわめて異なっており，これは異種の 活性中心から生成したものと考えられる。また, Table 2 の各コポリマー中のプタジェンの結合様式をみると cis-1,4 結合は 70 77\%, trans-1,4 結合は $21 \sim 28 \%$, 1,2 結合が $1 \sim 3 \%$ の籁囲内で変化する。同表に示すよ うにブタジェンの単独重合の場合にも結合様式は cis1,4 結合 $69 \sim 77 \%$, trans-1,4 結合 $22 \sim 30 \%, 1,2$ 結 合 1 3\% の籁囲内で変化する。2.4 に述べたように分

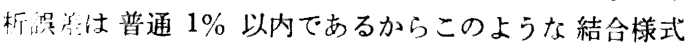
の違いは分析誤差によるものではなく, 触媒調製時や重 合中のわずかの条件の差,たとえば微量の不純物の存在, 触媒成分の添加の速さ, かきまぜの速さ, 反応系内の温 度などが異なることによって触媒の性質がわずかに変化 し，それによってブタジェンの結合様式が変化したので あろうと考えられる。イソプレンに扔いてはこのような 現象は全く見られなかったが，これは，この采の触媒を 用いた場合のインプレンの cis-1,4 重合の立体規則性 はきわめて强いのでこのようなことは起こらず，ブタジ エンは cis-1,4, trans-1,4 結合の混合構造でインプレ ンに比べてその重合の立体規則性はそれほど强くないの でわずかの条件の差によって重合の立体規則性が乱さ れるのであろらと推定される。
Table 5. Microstructure of polybutadiene (S-209*).

\begin{tabular}{c|c|c|c}
\hline & \multicolumn{3}{|c|}{ Microstructure (\%) } \\
\cline { 2 - 4 } & cis-1,4 & $\begin{array}{c}\text { trans- } \\
1,4\end{array}$ & 1,2 \\
\hline $\begin{array}{c}\text { Total polymer before } \\
\text { extraction }\end{array}$ & 76 & 23 & 1 \\
$\begin{array}{c}\text { Residue of ethylether } \\
\text { extraction }\end{array}$ & 32 & 67 & 1 \\
\hline (3 wt\% of total polymer) & & \\
\hline
\end{tabular}

* $\mathrm{Al} / \mathrm{Ti}=1.25$, Polymerization temperature $1 \sim 3^{\circ} \mathrm{C}$, Polymerization time $1 \mathrm{hr}$

\section{9 コポリマーの加硫試験}

2.6 に述べた処方でコポリマーおよび比較のために天 然ゴムと Ameripol CB を加硫し, 引張強さ, 伸び, 引 裂強さ，硬さなどを比較した。結果を Table 6 に示す。 コポリマーの聂が少なく単独では配合操作が困難だっ たのでこれに等量の天然ゴムを混合したものについて 試験した。試料が少量のため配合時のロール操作が長く なったものもあり，このようなものでは分子量の佐下が かなりおきていると考えられる。また，原料コポリマー の $[r]$ も不ぞろいなので, この結果からただちに結論を 導くことはできないが一応の目安とすることはできるで あろう加硫処方加硫条件なども最適のものかどうかわか らず，さらに検㶦する必要があるが，より適当な処方， 条件を選べばより良い結果が得られるものと思われる。 同表から判断すると、コポリマーは一般にポリブタジェ ン, 天然ゴム, Ameripol CB に少るこの原因の一つと して原料コポリマーの $[\eta]$ が低く, かつロール操作時間 が長くなったためさらに分子量の低下をひき起こしたこ とが考えられ，より高い分子量のものをつくればこれら に匹敵する性能を示すであろらと推定される。コポリマ 一の $[\eta]$ が不ぞろいなので組成と加硫物の性質の関係を 明らかにすることができなかったが，このためには [r] のそろったコポリマーを合成する必要がある。 
Table 6. Physical properties of vulcanized copolymers.

Blend: Sample polymer/Natural rubber $=50 / 50$

Recipe (phr): HAF black 50, Stearic acid 1.0, Zinc oxide 5.0, Nocceler CZ 1.2, Sulfur 2.3

Vulcanization: $138^{\circ} \mathrm{C}, 45 \mathrm{~min}$

\begin{tabular}{c|c|c|c|c|c|c|c|c}
\hline \hline $\begin{array}{c}\text { Sample } \\
\text { No. }\end{array}$ & $\begin{array}{c}\text { Isoprene content } \\
\text { in copolymer } \\
(\text { mol\%) }\end{array}$ & {$[\eta]^{*}$} & $\begin{array}{c}\text { Content of ben- } \\
\text { zene insoluble } \\
\text { part }\left(\mathrm{wt}_{\%}\right)\end{array}$ & $\begin{array}{c}\text { Hardness } \\
(\mathrm{JIS})\end{array}$ & $\begin{array}{c}\text { Tensile } \\
\text { strength } \\
\left(\mathrm{kg} / \mathrm{cm}^{2}\right)\end{array}$ & $\begin{array}{c}\text { Ultimate } \\
\text { elongation } \\
(\%)\end{array}$ & $\begin{array}{c}\text { Tear } \\
\text { resistance } \\
\left(\mathrm{kg} / \mathrm{cm}^{2}\right)\end{array}$ \\
\hline $\mathrm{S}-140$ & 100 & 1.82 & 25 & 68 & 133 & 280 & 54 \\
$\mathrm{~S}-141$ & 77 & 1.13 & 27 & 64 & 115 & 363 & 31 \\
$\mathrm{~S}-142$ & 54 & 0.76 & 16 & 66 & 171 & 350 & 71 \\
$\mathrm{~S}-143$ & 28 & 0.93 & 27 & 65 & 179 & 400 & 67 \\
$\mathrm{~S}-145$ & 0 & 1.27 & 24 & 63 & 198 & 453 & 86 \\
\hline & Ameripol CB & 2.02 & 0 & 65 & 254 & 460 & 84 \\
& Natural rubber & - & - & 68 & 243 & 357 & 102 \\
\hline
\end{tabular}

* measured at $25^{\circ} \mathrm{C}$ in toluene solution

$\mathrm{Al}\left(\mathrm{C}_{2} \mathrm{H}_{5}\right)_{3}-\mathrm{TiCl}_{4}$ 采触媒を用いて得た cis-1, 4 結合 $76 \%$ のポリブタジェンは引張強さ, 伸びとも良好で Ameripol CB より巳やや劣る程度であるが, Ameripo $\mathrm{CB}$ よりも分子量が低いことを考えに入れるとここで得 られたポリブタジェンは，Ameripol CB に匹敵する良 い性質をもっていると考えられる。

\section{4. ま め}

\section{1}

$\mathrm{Al}\left(\mathrm{C}_{2} \mathrm{H}_{5}\right)_{3}-\mathrm{TiCl}_{4}$ 系触媒を用いたブタジェンとイソプ レンの共重合にふらいては, ホモポリマーは生成せずコポ リマーのみが生成する。

4.2

コポリマーのベンゼン不溶分, 可溶分の組成およびミ ク口構造注しく, どちらも同じ多種類の活性中心から 生成したもので, 不浴分, 可溶分を生成する活性中心の 種類に区別はなく, 不溶分は可溶分が二次的な橋かけ反 応によって絴状化したものと考えられる。

4.3

組成の異なるコポリマーが存在することからこの系の 触媒には数種類の活性中心が存在すると推定され, この ことは既報 ${ }^{1)-31,8)}$ の結果からも支持される。

\section{4}

コポリマー中の両モ/マーの結合様式はホモポリマー の場合のそれと等しく、このことからブタジェンとイン プレンの組合せの場合には，共重台の際にも両モノマー はそれそれの重合の立体規勋性を互いに乱さないと推定 される。

4.5

触媒の $\mathrm{Al} / \mathrm{Ti}$ モル比が $1.25 \sim 1.50$ の範囲ではこれ
に無関倸に $r_{B} \fallingdotseq r_{I} \fallingdotseq 1$ である。

4.6

コポリマーはホモポリマーよりも分子量が低く, 両モ ノマーがほほ等モルの組成のコポリマーのそれが最も小 さい。これはポりマー鎖の生長末端に, 末端のモノマー 単位と異なる種類のモノマーが近づいた場合の方が，同 種のモノマーが近ついた場合よりも連鎖移動が起こりや すくなるためであろうと推定される。

4. 7

$\mathrm{Al}\left(\mathrm{C}_{2} \mathrm{H}_{5}\right)_{3}-\mathrm{TiCl}_{4}$ 系触媒を用いて合成した cis-1, 4 結 合 $76 \%$, trans-1,4 結合 $21 \%, 1,2$ 結合 $3 \%$ のポリブ タジェンの加硫物は天然ゴムや Ameripol CB に匹敵す るすぐれた機械的性質を示した。

付記：本研究は第 11 回商分子学会年次大会(昭和 37 年 5 月,名古屋)において発表した。

\section{文献}

1) 任江太郎, 山崎 升, 神原 周: 高化, 20, 262 (1963)

2) 住江太郎, 山崎 升, 神原 周: 高化, 20,461 (1963)

3) 住江太郎：高化, 20, 467(1963)

4) 山崎 升, 任江太郎, 神原 周: 工化, 64, 1507 (1961)

5) D. Morero: Chim. e Ind., 41, 758(1959)

6) 神原 周, 山崎 升, 住江太郎：工化, 62, 299 (1959)

7) N. Gaylord, T. Kwei, H. Mark: J. Polymer Sci., 42, 417(1960)

8) 山崎 升, 住江太郎, 古浜睡英, 神原 周: 工化, 64, 1687 (1961) 


\title{
Copolymerization of Butadiene and Isoprene by Ziegler Type Catalyst
}

\author{
By Taro Suminoe*, Kiiti Sasaki**, Noboru Yamazaki** and \\ Shu Kambara**
}

In the copolymerization of butadiene and isoprene by $\mathrm{Al}\left(\mathrm{C}_{2} \mathrm{H}_{5}\right)_{3} \mathrm{TiCl}_{4}$ catalyst, following results were obtained. $\mathrm{Al} / \mathrm{Ti}$ mole ratio, in the range of 1.25 to 1.50 , had no effect on the monomer reactive ratios (both $r_{B}$ and $r_{I}$ were near unity), but the reaction rate of copolymerization falled markedly with changing $\mathrm{Al} / \mathrm{Ti}$ ratio from 1.25 to 1.50 . Copolymers consisted of either benzene soluble and insoluble parts, their composition and microstructure being almost the same each other. By the fractional precipitaion method, the benzene soluble part was fractionated into several fractions, all of which had the same microstructures but the different compositions and viscosities. The microstructures of butadiene and isoprene unit in the copolymers were same as that in the homopolymers obtained under the same polymerization condition. The intrinsic viscosities of copolymers were smaller than those of homopolymers and that of $50 / 50$ copolymers was the minimum.

From these results, it was concluded that the above results gave a support to the assumption on the multiplicity of active sites in Ziegler type catalysts proposed in the previous papers. In the copolymerization of butadiene and isoprene, the stereospecific addition of the entering monomer did not depend on the kind of the monomer unit of the growing chain end. The cross-transfer reaction occured more easily than the transfer reaction towards the same monomer as the growing end.

* Kyowa Hakko Kogyo Co. Ltd. (Otemachi, Chiyoda, Tokyo) Present Address: Japan Synthetic Rubber Co. (Kawajiri, Yokkaichi, Mie)

** Tokyo Institute of Technology (Ookayama, Meguro, Tokyo) 